\title{
Programação diversificada
}

Estamos vivendo mais e melhor. Considerando-se a natureza humana, o passar do tempo traz consigo potenciais mórbidos que provocam impactos na vida, entre os quais temos as doenças crônicas que implicam mudanças físicas e emocionais, que, por sua vez, levam à diminuição da produtividade humana.

Atualmente, cerca de $60 \%$ dos óbitos mundiais são devidos às doenças crônicas. Com a melhoria da qualidade de vida e do ambiente no planeta e, conseqüente, o controle de doenças infecciosas espera-se que nas próximas décadas as doenças crônicas sejam responsáveis por cerca de 75\% dos óbitos.

Não poderíamos deixar de abordar este tema no $40^{\circ}$ Congresso Brasileiro de Patologia Clínica/Medicina Laboratorial, dando-lhe a importância que merece. Três conferências magnas darão o norte do nosso evento: uma relacionada à medicina preventiva, outra abordando o tema da medicina preditiva e, por fim, uma que traga uma vertente mais inovadora: a medicina regenerativa.

Elaboramos um programa prático com várias atividades simultâneas dirigido ao nosso maior público: vocês. Esperamos que mais uma vez vocês tenham oportunidade de se atualizar e se deparar com novos desafios na medicina laboratorial.

Aguardamos vocês em Curitiba! 